\title{
Work Engagement in the Work Place: The Role of Procedural Justice, Perceived Organizational Support and Organizational Trust
}

\author{
Praptini Yulianti \\ Department of Management \\ Airlangga University, Indonesia
}

\begin{abstract}
Employee engagement in the workplace is very important, especially for the organizational competitive advantage. Employee engagement in the workplace can be built through procedural justice, perceived organizational support and organizational trust. This research is an explanatory research that will explain the causal relationship between variables or through hypothesis testing. The sample in this study was collected through 118 respondents. The criteria of the selected respondents were the ones that working in the production division, since production division is the core of industrial companies. The sampling technique in this study used Partial Least Square. The results of this study supports the relationship between procedural justice and perceived organizational support with employee engagement either directly or with the mediation of organizational trust.
\end{abstract}

Keywords : Procedural Justice, Perceived Organizational Support, Organizational Trust, Employee Engagement

\section{INTRODUCTION}

When an economic recession happened in 2008, many companies in the world have begun to realize the importance of the human role in organization. Many companies have started to be more focused to manage the human capital of the company. Employee engagement in the workplace has contributed its role for company performances and competitive advantages. Company's role is not only doing the recruitment and retaining their best employees but also expecting them to have an emotional attachment toward the company and their work.

The result of Employee engagement measurement in the world shows an upward trend, while in Asia Pacific is still very low (Aon Hewitt, Download, March, 2015). Employee engagement in Indonesia is still at its lowest level in Asia Pacific, but in Southeast Asia, Indonesia is still better than Malaysia (Aon Hewitt, Download, March, 2015). Employee engagement has a very strong effect on the employees' performance compared with the effect of the intrinsic motivation, involvement, and job satisfaction. Employee engagement reflects the happiness of the employee rather than the job satisfaction. (Rich et al., 2010).

High Employee engagement is showed by Say, Stay and Strive of the employees (Aon Hewitt, Download, as of March, 2015). Say is to speak positively about the organization to co-workers, potential employees and customers. Stay is to have an intense desire to be a member of the organization, and Strive is the behavior of the employee that they will do their best to achieve the organization business success.

Furthermore, Employee engagement is not just a physical presence in the organization, but it's more about emotional attachment which shown by the employees' focus on their performance. 
Schaufeli et al. (2003) explained that employees who have engagement on their job will be more energetic, enthusiastic, and happy in carrying out their work. Those employees will also have the initiative and can contribute in enhancing innovation for their company (Hakanen et al., 2008).

Macey et al. (2009: 13) states that if employees are treated fairly, then they will have engagement on the job. Employees that are treated with procedural fairness will believe and trust their organization which can influence employee engagement at work (Chughtai and Finian, 2009).

Theoretically, procedural justice is based on the social exchange relationship between the employee and the organization. The law of reciprocity states that a person who was being treated fairly by the others will feel obliged to treat the others with a good treatment as well (Blau, 1964: 88). A good treatment that is received by the employees will be able to increase employees' trust toward their organization. Empirical studies have shown that trust in the organization has been linked with positive attitude in the workplace. When employee believes in organization, the norms of reciprocity will happen and the employee will exchange the good treatment from the organization with strong engagement with their job.

The total number of labor force in Indonesia per February 2014 has increased by 5.2 million people compared to August 2013, but the employment structure has not changed, in which Agriculture, Trade, and Industry Sectors are still the biggest employers in Indonesia (BPS, 2014).But if the number of the labor force increasing without the number of the employment, it can lead to the unfair treated from the company to its employee, and it will block up the development of trust in the organization.

But the unfairness in determining the rewards for the employee in those sectors are still happened, it is showed by the cause of the protests is often demanding salary increases. That unfairness occurs due to the low gain of employment and the low levels of education of the workforces. In Indonesia elementary levels workforces are still dominating (46.80 percent), while Diploma level workforces are around 3.1 million people (2.65 percent) and workforces with University level are just 8.8 million people (7.49 percent) (BPS, 2014). The low gain employment and low educational levels of the workers led to industrial companies assuming that those workers are not a part of human capital, but as a cost which affects the unfair treatment.

Employee engagement can also be built through perceived organizational support. Many studies have recognized that organization is an important source of socio-emotional development for its member (Van Dyne et al. 1994; Organ (1988) in Organ et al. (2006: 251); Van Scooter \& Motowidlo (1996); William \& Anderson, 1991 and Coleman and Borman, 2000). Hawthorne's research around 1930 (Wren, 2005: 279) have described that an organization is an important source of socio-emotional development for its members. The results of Hawthorne's study shows that employees who has more flexible and shorter working hours had better attitudes and higher productivity than employees who did not get any benefits from the organization. Hawthorne studies showed that if organization considers the employees as valuable human capital and notices them by giving them favorable treatment, the employees will have higher level of productivity and positive attitude toward their organization. The confidence level of the organization' members will be influenced by their evaluation of their experiences and observations about how the organization treats its members in general (Allen \& Meyer, 1990; Eisenberger \& Rhoades, 2002). 
Based on the description that has been described previously, the focus of this research is to build employee engagement through procedural justice and perceived organizational support that mediated by organizational trusts of employees in the industrial company.

\section{Procedural Justice}

\section{THEORY AND HYPOTHESES}

Procedural justice is the procedures that are used by the organization to distribute the results and the resources of the organization to its members. Procedural justice in an organization will be more about the implementation of formal regulations that exist in the organization. Colquitt (2001) describes that procedural justice is a process of the procedural rules in an organization, such as consistent, unbiased, accurate and ethical. Those rules become one assessment of employees' perception to see the organizational level of procedural. Procedural fairness include: a) Structural components: the organization's policy and regulatory that are based from the employees' opinion or their feedback to the organization, b) Informational components: organizations explanation about the decision that has been made. c). Interactional components: the quality of the interpersonal treatment received by employees.

\section{Perceived Organizational Support}

Perceived Organizational Support (POS) is an important concept for explaining the relationship between the organizations treatment toward their members with the attitude and behavior of the organization's members toward their jobs and or the organization. The basic concept of Perceived Organizational Support (POS) recently introduced and measured in 1986 by Eisenberger et al. (1986). Eisenberger and Rhoades (2002) define Perceived Organizational Support (POS) as employee perceptions of the organizational support for its members to have a better life. The perception of the organization's members about their organization will deliver a certain level of confidence from the organization's members because of the rewards that are given to them by the organization for their contributions (valuation of the employee's contribution) and the organization's attention on quality of life (care about employee's wellbeing).

\section{Work Engagement}

Work engagement concept was introduced by Kahn (1990). Work engagement is defined by Kahn (1990) as "the use of the organization's member role in their work". Maslach and Leiter (1997) defined Work engagement as the opposite of burnout, energy, engagement, and sense of efficacy. But Schaufeli et al. (2003) did not conceptualize work engagement as an opposite of burnout. Work engagement is a positive motivational condition for the employees' self-esteem. Work engagement is a combination of high energy (spirit) and strong engagement.

Schaufeli et al., (2003) took a different approach about work engagement's concept, he conceptualizes it as a positive antithesis to burnout, as claimed by Maslach and Leiter (1997). Work engagement is defined as something positive, fulfilling the obligations, and related to the mind, it's characterized by psychic powers, dedication, and absorption (Schaufeli et al., 2003). Psychic power is showed through the high levels of energy and mental abilities while working, willingness to invest more efforts to the job, even the continuing to do the job despite the difficulties. Dedication is showed through a strong involvement on the job and a sense of enthusiasm, inspiration, pride, and challenge. Absorption is showed through the concentration and interest of the employees' in their job that made the employees happy, feel that the times pass quickly and find it difficult to leave his/her job (Saks, 2006). 


\section{Trust}

Trust according to Mayer et al. (1995) is: "The willingness of a party to be vulnerable to the actions of another party based on the expectation that the other party will perform a particular action important to the trustor, irrespective of the ability to monitor or control that other party". Empirical study by Mayer et al. (1995) and Schoorman et al. (1996) explained that trust will be able to enhance the ability of the employees on doing teamwork and the employees who trust their organization will expand their role in the work especially on doing their teamwork.

According to social exchange theory, people will support the social exchange as long as they get the benefits that were given by the partner (Blau, 1964). Mayer et al. (1995) suggested that trust is based on the expectation that others will commit acts that are considered important by the trustor, without the need to be monitored or controlled by the trustor (Brockneret al., 1997). Mayer et al., (1995) argued that something or someone that considered as reliable is depend on their ability, benevolence, and individual integrity. Integrity shown by someone's honesty in a relationship, often cited as a basis of trust and may be formed by procedural justice (Brockner et al., 1997). If the procedure used by the trustee is seen as procedurally fair by the trustor, there's no need to monitor the trustee. Someone who is considered to be kind and like to help the others is usually likeable, and consequently considered to be trustworthy.

A leader should have the ability to develop the trust level of the employees in the organization. Skill, competence and relevant personalities found as an integral part of the ability (Mayer et al., 1995). Trust also refers to the expectations of the kindness (benevolence) and integrity (Schoorman et al., 1996).

\section{RELATIONSHIPS BETWEEN VARIABLES \\ The influence of Procedural Justice and Perceived Organizational Support to Employee Engagement}

The relationship between perceived organizational support and procedural justice with Employee Engagement can be seen in the perspective of the social exchange theory. The employees that are treated procedurally fairly and appreciated by the organization, they will exchange it with the behavior that is expected by the organization. Procedural justice include fairness in the treatment and fairness in the decision-making process. Perceived Organizational Support is the level of their confidence that the organization notice and pay attention about their existence and give full support to their works and welfares. Organizations that treat their members with fair, support them, and care about their welfare will get dedication and the best result from the employees'. Based on the statements, the hypothesis is :

H1 \& H2: Procedural Justice and perceived organizational support has positive effect on employee engagement.

\section{The influence of procedural justice on Trust}

Stinglhamber, Florence et al. (2006) stated "There is a relationship between procedural justice and trust." The social exchange theory (Blau, 1964) is a theoretical framework that is predominantly used to examine the relationship of employees in the literature of organizational psychology (Setton, Bennett, \& Liden , 1996; Wayne, Shore, \& Liden, 1997). According to Blau (1964), trust plays an important role in these relations to be a mechanism which later will give a result that justice will affect the employees' outcome. Aryee et al. (2002) examined the relationship between procedural justice and trust in the workplace. Mayer et al. (1995) suggested that fair treatment will develop employees' trust. Fair treatment that's 
received by the employees will make them believe that in the future they will be treated fairly as well. Based on the statement, the hypothesis is :

H 3: Procedural Justice has a positive effect on employees' trust in the organization

\section{The influence of Perceived Organizational Support onTrust in Organizations}

Perceptions organizational support (POS) is theoretically based on the social exchange relationship between the employee and the organization. The law of reciprocity states that a person that is being treated fairly by the other party will feel obliged to reciprocate it with good treatment as well (Blau,1964: 88). Furthermore, Eisenberger et al. (1990) in Coyle et al. (2004) found Perceived Organizational Support as the foundation of trust. The good treatments that are received by the employees will be able to develop the employees'trust of in organization. Employees' perception of organizational support (POS) through the rewards that are given by organization based on their contributions (valuation of the employee's contribution) and the organization's attention about their life (care about employee's wellbeing) (Eisenberger \& Rhoades, 2002) will grow the employee's trust in the organization. Based on the statement, the hypothesis is :

H 4: Perceived Organizational Support has a positive effect to employee's trust in the organization

\section{The influence of Trust in the organization to Employee Engagement}

Trust in the organization can lead to higher Work Engagement, when employees believe in the organization; they will focus to the achievement the organizational goals. The employees will do their task full of dedicated (Kahn, 1990; Rothbard, 2001). Employees will trust their organization if their leaders have the ability, benevolence and integrity. Trust in the organization lead to the positive motivation of the employees to work with more energy, passion and dedication. Based on the statement, the hypothesis is :

H 5: Trust in the organization has a positive effect on Employee Engagement

\section{Conceptual Framework}

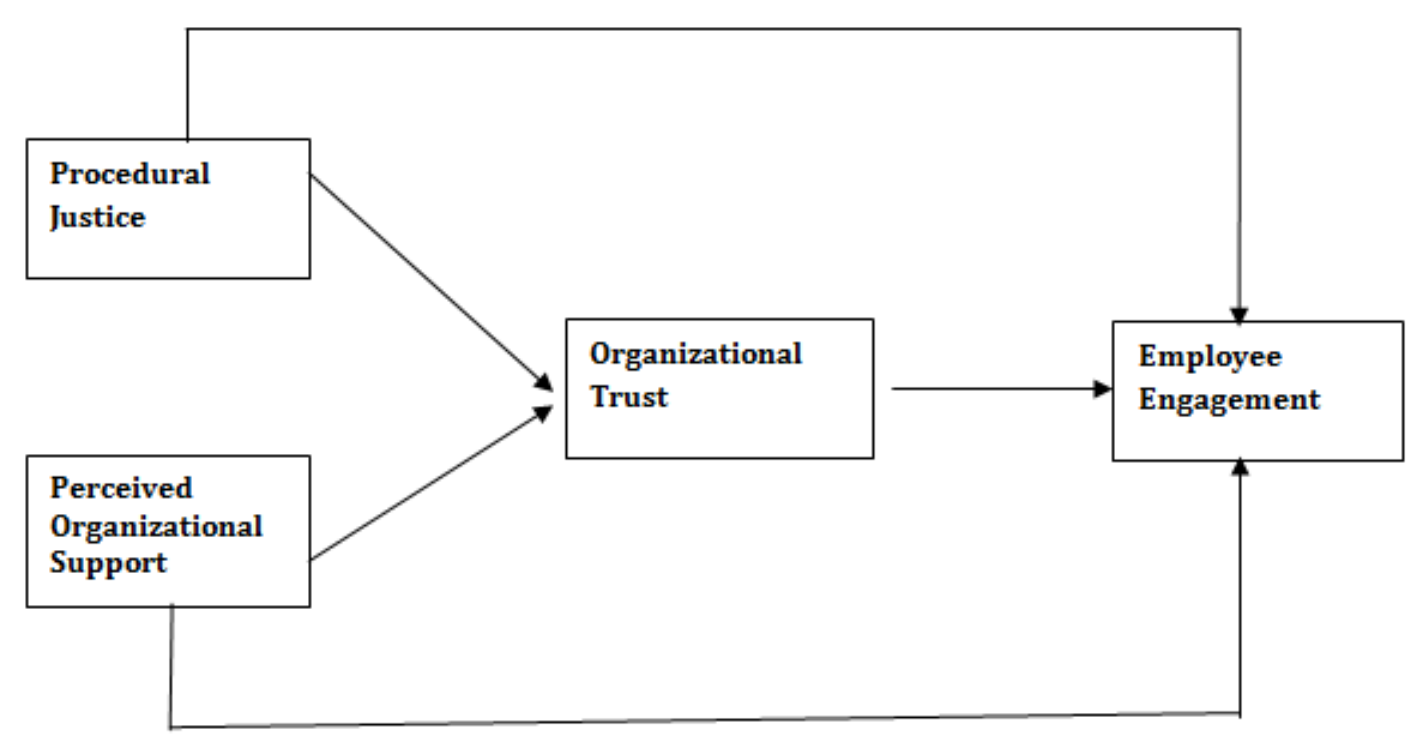




\section{METHOD}

The samples in this study were the employees in the industrial company. The selected respondents are the ones working in the production division, since production is a major part in industrial companies. The questionnaires were distributed conducted through online media, 124 questionnaires were answered but the questioners that met the criteria are only 118 questionnaires. The examples of industrial companies are printing, chemicals and household items companies. The various types of company has done different test and there is no significant different showed in the result.

\section{Procedural Justice}

\section{MEASURES}

Procedural justice is respondents' perception of fair treatment received by them from their organization, both in the way the organization treat their employees and the justice policy created for employees. Measurement indicator is adopted from the scale developed by Shore and Shore (1995).

\section{Employee Engagement}

Employee Engagement is respondents' perception of the level of energy, strong involvement in work and concentration as well as the interest that makes them happy when doing their works. Measurement indicator is adopted from the scale developed by Schaufeli et al. (2003) scale.

\section{Trust}

Trust in the organization is measured by three indicators: ability, kindness (Benevolence) and Integrity. Measurement indicator is adopted from the scale developed by Mayer et al. (1995).

\section{Perceived Organizational Support}

Perceived Organizational Support using 8 indicators adopted from Survey of Perceived Organizational Support that has been developed by Eisenberger and Rhoades (2002). 


\section{RESULT}

Table 1. Validity Test

\begin{tabular}{|c|c|c|c|c|}
\hline Variable & Indicator & Outer Loading & $\begin{array}{l}\text { Standar } \\
\text { Loading }\end{array}$ & Result \\
\hline \multirow[t]{2}{*}{ Procedural Justice } & PJ 1 & 0,776 & 0,5 & Valid \\
\hline & PJ 2 & 0,813 & 0,5 & Valid \\
\hline \multirow{8}{*}{$\begin{array}{l}\text { PERCEIVED ORGANIZATIONAL } \\
\text { SUPPORT }\end{array}$} & POS 1 & 0,670 & 0,5 & Valid \\
\hline & POS 2 & 0,754 & 0,5 & Valid \\
\hline & POS 3 & 0,894 & 0,5 & Valid \\
\hline & POS 4 & 0,842 & 0,5 & Valid \\
\hline & POS 5 & 0,856 & 0,5 & Valid \\
\hline & POS 6 & 0,757 & 0,5 & Valid \\
\hline & POS 7 & 0,504 & 0,5 & Valid \\
\hline & $\operatorname{POS} 8$ & 0,873 & 0,5 & Valid \\
\hline \multirow[t]{3}{*}{ ORGANIZATIONAL TRUST } & от1 & 0,809 & 0,5 & Valid \\
\hline & от2 & 0,863 & 0,5 & Valid \\
\hline & отз & 0,868 & 0,5 & Valid \\
\hline \multirow[t]{3}{*}{ EMPLOYEE ENGAGEMENT } & WE1 & 0,749 & 0,5 & Valid \\
\hline & WE2 & 0,735 & 0,5 & Valid \\
\hline & WE3 & 0,687 & 0,5 & Valid \\
\hline
\end{tabular}

Table 2. Reliability Test

\begin{tabular}{|c|c|c|c|}
\hline \multirow[b]{2}{*}{ Variable } & \multirow[t]{2}{*}{ Critical Value } & \multicolumn{2}{|c|}{ Estimation } \\
\hline & & $\begin{array}{c}\text { Cronbach Alpha } \\
(\alpha)\end{array}$ & Result \\
\hline Procedural Justice & 0,6 & 0.893413 & Reliabel \\
\hline Perceived Organizational Support & 0,6 & 0.748786 & Reliabel \\
\hline Organizational Trust & 0,6 & 0.843632 & Reliabel \\
\hline Employee Engagement & 0,6 & 0.953033 & Reliabel \\
\hline
\end{tabular}

Table 3. Determination Cofficient

\begin{tabular}{|l|c|}
\hline \multicolumn{1}{|c|}{ Variable } & $\mathrm{R}^{2}$ \\
\hline Procedural Justice $\rightarrow$ Employee Engagement & 0,349 \\
\hline Perceived Organizational Support $\rightarrow$ Employee Engagement & 0,279 \\
\hline Procedural Justice $\rightarrow$ Organizational Trust & 0,309 \\
\hline Perceived Organizational Support $\rightarrow$ Organizational Trust & 0,202 \\
\hline Organizational Trust $\rightarrow$ Employee Engagement & $\mathbf{0 , 2 0 7}$ \\
\hline
\end{tabular}


Table 4. T-Test

\begin{tabular}{|c|c|c|c|c|c|c|}
\hline Hypothesis & Endogen Variable & $\Rightarrow$ & Exogen Variable & $\mathrm{T}$-Table & T- Statistic & Result \\
\hline H1 & Procedural Justice & $\Rightarrow$ & $\begin{array}{c}\text { Employee } \\
\text { Engagement }\end{array}$ & 1,96 & 4,321 & Significant \\
\hline $\mathrm{H} 2$ & $\begin{array}{c}\text { Perceived } \\
\text { Organizational } \\
\text { Support }\end{array}$ & $\Rightarrow$ & $\begin{array}{c}\text { Employee } \\
\text { Engagement }\end{array}$ & 1,96 & 3,391 & Significant \\
\hline H3 & Procedural Justice & $\Rightarrow$ & $\begin{array}{c}\text { Organizational } \\
\text { Trust }\end{array}$ & 1,96 & 4,667 & Significant \\
\hline H4 & $\begin{array}{c}\text { Perceived } \\
\text { Organizational } \\
\text { Support }\end{array}$ & $\Rightarrow$ & $\begin{array}{c}\text { Organizational } \\
\text { Trust }\end{array}$ & 1,96 & 3,100 & Significant \\
\hline H5 & Organizational Trust & $\Rightarrow$ & $\begin{array}{c}\text { Employee } \\
\text { Engagement }\end{array}$ & 1,96 & 3,211 & Significant \\
\hline
\end{tabular}

Hypotheses are tested using the Partial Least Square (PLS). Using outer and inner testing models. Outer model is used to test the construct of the validity and reliability. An inner testing model is used to test the relation between variables. Tests carried out using t-test. Validity and reliability testing can be seen in table 1 and 2 . All indicators are valid and reliable. In Table 3 shows the relationship between variables and as can be seen in the table 4 , employee engagement has significant relation to both procedural justice and perceived organization support. Organizational trust was significantly and positively correlated with procedural justice and perceived organizational support. Organizational trust was significantly and positively correlated with employee engagement. Organizational Trust acts as a partial mediating in the relationship between perceived procedural justices with organizational support employee engagement.

\section{Theoretical Implications}

\section{DISCUSSION}

The main objective of this study is to prove that employee engagement in the workplace affected by the procedural justice, perceived organizational support and organizational trust. Results of studies have proven that organizations that procedural justice and organizational support perceived effect on employee engagement. Results of this study also proves that the Organizational trusts acts as a mediation to both the relation between procedural justice relationship with employee engagement and organizational support perceived relationship with employee engagement. Procedural justice and perceived organizational support can directly affect employee engagement. Procedural justice and perceived organizational support can also affect employee engagement through organizational trust. Results of this study proves that procedural justice has a great influence both on organizational trust and employee engagement (see table 3). Results of this study also proves that procedural justice has motivated the employees' to engage with their work. The study is also justifying the social exchange theory, someone who is being treated fairly by the other party will feel the obligated to reciprocate it with good treatment as well (Blau, 1964: 25). Perceived organizational support will develop organizational trust of the employees. Confidence level of theorganization's members about the Organizational support is influenced by their evaluation of the experiences and observations about how the organization treats them in general (Allen \& Meyer, 1990; Eisenberger and Rhoades, 2002). Organizational trust will be able to motivate employees to engage in the work.

\section{Practical Implications}

The findings of this study shows that procedural justice plays a major role in building employee engagement. Procedural justice what employees feel in everyday work, so if 
employees are treated procedurally unfair, it will affect the employee engagement. Employees who receive procedural justice in both the way they are treated and their voices are heard by the organization, will trust the organization. Procedural justice in this case is the response of the employees about the treated they received and procedural fairness provided by the organization in making policies for employees. Justice is the way employees feel that the organization has to be fair in giving tasks, providing opportunities for self-development, and applying the rules and policies to all employees.

Other findings from this study shows that perceived organizational support has also contributed in building employee engagement but not as big as the role of procedural justice. Procedural justice has bigger role than comparison to the role of organizational support, support work's facilities and the awareness of employees'welfare.

Employees of production division in industrial company are very sensitive to unfair treatment.The increase numbers of workforce that are not followed by the increase numbers of employment in Indonesia led to unfair treatment received by the employees. Employees need fairness, especially the unfair treatment from their supervisors and they want their voices to be heard and used in making the organization's policies. Employees, who feel the existence of procedural fairness, will believe that their leaders have the ability, integrity and concern about them.

\section{References}

Allen, Natalie J. dan Meyer, J.P. (1990). The Measurement and Antecedent of Affective, Continuance and Normative Commitment to The Organization. Journal of Occupational Psychology, 63, 1-18.

Aryee, S., Budhwar, P. S., \& Chen, Z. X. (2002). Trust as a mediator of the relationship between organizational justice and work outcomes: Test of a social exchange model. Journal of Organizational Behavior, 23, 267-285.

Blau, P. (1964). Exchange and Power in Social Life. New York : Wiley.

Brockner, Joel, Phyllis A., Siegel, Joseph P., Daly, and Christopher Martin. (1997). When trust matters : The moderating effect of outcome favorability. Administrative Science Quarterly 42 (September) , 558-83

Chughtai, Aamir A. and Finian, Buckley. (2009). Linking Trust in the Principal to School Outcomes: The Mediating Role of Organizational Identification and Work Engagement. International Journal of Educational Management, 23(7), 574-589.

Coleman, V. I. danBorman, W. C. (2000). Investigating the Underlying Structure of the Citizenship Performance Domain. Human Resource Management Review, 10, 25-44.

Colquitt, J.A. (2001). On The dimensionality of Organizational Justice : a Construct Validation of a measure. Journal of Applied Psychology. 86, 386-400.

Coyle-Shapiro, J., I. Kessler, dan J. Purcell. (2004). Exploring Organizationally directed Citizenship Behavior : Reciprocity or 'it's My Job. Journal of ManagementStudies, 41, 85-106

Eisenberger, R.,dan Rhoades, L. (2002). Perceived Supervisor Support : Contributions to Perceived Organizational Support and Employee Retention. Journal ofApplied Psychology, 87, 565-573.

Hakanen, J. J., Perhoniemi, R., \&Toppinen-Tanner, S.(2008). Positive gain spirals at work: From job resources to work engagement, personal initiative and work-unit innovativeness. Journal of Vocational Behavior, .73(1), 7891.

Kahn, W.A. (1990). Psychological conditions of personal engagement and disengagement at work. Academy of Management Journal, 33, 692-724.

Macey, W.H., Schneider, B., Barbera, K.M. and Young, S.A. (2011), Employee Engagement: Tools for Analysis, Practice, and Competitive Advantage, Wiley-Blackwell, Malden, MA.

Maslach,C. and Leiter, M.P. (1997). The Truth about Burnout : How Organizations Cause Personal Stress and What to Do about it. San Fransisco, CA : Jossey Bass. 
Mayer,Roger C., James H.Davis, and F. David Schoorman. (1995). An integrative model of organizational trust. Academy of Management Review Vol. 20(3), 709- 34.

Organ, D.W., Podsakoff, P.Mdan S.B. MacKenzie, S.B. (2006). Organizational Citizenship Behavior: Its Nature, Antecedents, and Consequences, Thousand Oaks, CA : Sage.

Rich, B. L., Lepine, J. A., and Crawford, E. R.(2010) . Job engagement :

Antecedents and effects on job performance. Academy o Management Journal. 53, 617-635.

Rothbard,N.P. (2001). Enriching or Depleting ? The dynamics of engagement in work and family roles. Administrative Science Quarterly,46, 655-684

Saks, A.M. (200 ). , “Antecedents and consequences of employee engagement”, Journal of Managerial Psychology, 21(5), 600-619

Schaufeli, W.B. and Bakker.A. (2003). Utrecht Work Engagement Scale. Preliminary Manual. Occupational Health Psychology Unit, Ultrecht University

Schoorman,F. David,Roger C. Mayer, and James H. Davis. (1996) Empowerment in veterinary clinics : The role of trust in delegation. Paper presented at Society for Industrial and Organizational Psychology, San Diego.

Settoon, R. P., N. Bennet and R. C. Liden. (1996). Social Exchange in Organizations: The Differential Effects of Perceived Organizational Support and Leader Member Exchange. Journal of Applied Psychology, 81, $219-239$.

Shore, L. M. dan Shore, T. H. (1995). Perceived organizational Support and Organizational Justice. In R. S. Cropanzano and K. M. Kacmar (Eds.), Organizational Politics,Justice, and Support: Managing the Social Climate of the Workplace, Westport, CT: Quorum Super, D, 149-164.

Stinglhamber, Florence, David De Cremer and LiesbethMercken.(2006). Perceived Support as a Mediator of The Relationship Between Justice and Trust. Group \& Organization Management, 31(4), 44

Van Dyne, L., Graham, J. W. danDienesch, R. M. (1994). Organizational Citizenship Behavior: Construct Redefinition, Measurement, and Validation. Academy of Management Journal. 37(4),765 -802.

Van Scotter, J. R. danMotowidlo, S. J. (1996). Evidence for Two Factors of Contextual Performance: Job Dedication and Interpersonal Facilitation. Journal of Applied Psychology, 81, 525-531.

Wayne, S. J., Shore, L. M., andLiden, R. C. (1997). Perceived Organizational Support and Leader Member Exchange: A Social Exchange Perspective. Academy of Management Journal, 40, 82-111

Williams, L. J. dan Anderson, S. E. (1991). Job Satisfaction and Organizational Commitment as Predictors of Organizational Citizenship and In Role Behaviours. Journal of Management, 17, 601-617.

Wren, Daniel A. (2005). The History of Management Thought, Fifth Edition, United States of America : John Wiley and Sons, Inc. 